\title{
Chronic Subdural Hematoma: Concepts of Physiopathogenesis A Review
}

\author{
ENRIQUE L. LABADIE and DAVID GLOVER
}

\begin{abstract}
SUMMARY: From the present review it seems clear that the physiopathogenesis of the chronic subdural hematoma is far from being completely understood. However, an analysis of the known data can be summarized as follows:

The development of subdural hematomas most likely occurs following minimal trauma in those patients with predisposing factors.

Experimental data substantiates the fact that an accumulation of clotted blood in the subdural or subcutaneous space induces the formation of the fibroplastic neomembrane. The hypothesis that blood must come in contact with cerebrospinal fluid in order for the growth to occur, is still controversial.
\end{abstract}

(Turn to page 224)

RÉSUMÉ: Il semble clair que la physiopathogénèse de l'hématome sousdural chronique est loin d'être bien comprise. Cependant, une analyse des données connues peut ainsi se résumer:

- Le développement d'un hématome sousdural peut se produire après un traumatisme minime chez les patients prédisposés.

- Des données expérimentales indiquent qu-une accumulation de caillots de sang dans l'espace sousdural ou sous-cutané entraine la formation d'une néomembrane fibroplastique. L'hypothèse selon laquelle le sang doit entrer en contact avec le liquide céphalorachidien pour que se produise la croissance, est encore contreversée.

(Suite à la page 224)

Departments of Neurology and Clinical Pathology, University of Arizona Medical Center, Tucson, Arizona.

Reprint requests to Dr. E. L. Labadie, Dept. of Neurology, The University of Arizona, Arizona Medical Center, Tucson, Arizona 85724 U.S.A.
According to Peery and Miller (1971), a chronic subdural hematoma usually results from a rupture of a bridging vein that crosses the subdural space from the arachnoid membrane to the dura mater. The most common etiologic factor is trauma, but chronic subdural hematomas have been observed in patients on anticoagulant therapy (Dooley and Perlmutter, 1964; Gardus, 1964; Sveerama et al, 1973; Capistrant et al, 1971), hemodialysis therapy, low pressure syndromes (Leonard et al, 1969; Tallala et al, 1970; Bechar et al, 1972; Zarowny and Rose, 1970), and as a complication in hemophilia (Kerr, 1964), chemotherapy in acute lymphatic leukemia (Belmusto et al, 1964; Wolcot et al, 1970), bleeding intracranial aneurysms (Boop et al, 1961; Clark and Walton, 1953), and following epileptic convulsions (Arieff and Wetzel, 1964). Chronic alcoholism is known to be a rather common preexisting condition, but occasionally no known predisposing factors are evident.

Onset of symptoms may be sudden (Wells, 1892) or insidious. They are classified by Putnam and Cushing (1925) as those due to increased intracranial pressure (headache, vomiting, vertigo, slow pulse, choked discs); those due to local pressure (paralysis, convulsions, aphasia); those due to irritation (Kernig's sign, stiff neck). Fluctuating dementias are also commonly present (Labadie and Glover, 1974). Other changes in the brain include hemorrhage into the optic sheaths (Zacher, 1833) and destruction of the eighth nerve (Kasemyer, 1912).
Clinically, symptoms appear after a latent interval, generally about 3 to 6 weeks; the hematoma enlarges slowly, and a volume of at least 40 $\mathrm{ml}$. is probably necessary for significant cerebral compression (Aronson, 1960).

The lesion itself contains a fluid, presumably blood initially, which may be dark brown to xanthochromic in color. The outer wall of the sac is surrounded by a "highly vascular layer of granulation tissue" (Gardner, 1932) while the inner wall, closest to the arachnoid, consists of a relatively thin layer of avascular fibrous tissue which is characteristically non-adherent to the arachnoid. This newly formed sac tissue is called the neomembrane.

The physiopathogenesis of the subdural hematoma enlargement has been a subject of debate for nearly 150 years. Early proposed theories were predominantly those of a continuous and gradual hemorrhage into the subdural cavity (Bayle, 1826; Virchow, 1863), inflammation as a principal means of growth (Heschl, 1855; Cruveilhier, 1856), and that the subdural hematoma was primarily an abscess (Glaser, 1886; Kluck, 1890). The latter hypothesis was subsequently disproven, and only rarely is a truly infectious case seen (Lerner et al, 1972).

Gardner (1932) proposed the hypothesis that traumatic subdural hematoma enlargement was due primarily to fluid drawn into the lesion by the "osmotic tensions of the blood proteins contained in the cyst." But although Gardner demonstrated that blood has a great affinity for the water content of cere- 
brospinal fluid, when both fluids are separated by a semipermeable membrane (cellophane), his experiment using a portion of the inner cyst wall from a subdural hematoma showed only a modest increase in volume of 2.9 per cent within 16 hours. It should be noted that the "osmotic" properties of a given fluid, when measured by freezingpoint depression, are similar but not the same as the "oncotic" gradient exerted by proteins in a solution, and confusion in regard to these two terms is frequently seen in the pertinent literature. Thus, Gardner's hypothesis is, by definition, an oncotic gradient theory.

Zollinger and Gross (1934) published evidence from in vitro studies that showed that red cell disintegration within the hematoma produced a significant increment in the effective "osmotic" (oncotic) pressure gradient. They utilized a lysed whole blood filled subdural hematoma sac which was connected to a graduated manometer. When the sac and its contents were then immersed in isotonic saline, it resulted in an average rise of fluid of $89 \mathrm{~cm}$. in the measuring column. Although the authors believed the rise in fluid was due to osmotic phenomena, the blood and the saline were essentially iso-osmotic as measured by freezing point depression. Therefore, the pressure gradient was exerted by the blood proteins across the semipermeable membrane of the subdural sac, and was oncotic in nature.

A study of 105 cases by Munro and Merritt (1936) revealed a progressive dilution of subdural fluid as determined by assay of the total protein content. These authors believed this to be compatible with the "osmotic-(oncotic) gradient theory" as the "diminution in the rate of dilution being progressively more marked as the percentage of protein in the solution grows less." They also proposed that the arachnoid acted as a dialyzing membrane permitting the entry of cerebrospinal fluid (C.S.F.) into the enlarging subdural cavity. To date, there has been no published evidence either to support or to refute the latter hypothesis.
It is also significant to note that Weir (1971), using freezing point depression measurements, detected no significant difference when he compared the osmolalities of subdural hematoma fluid, venous blood, and lumbar cerebrospinal fluid, in some 23 cases.

Chemical determinations by Gitlin (1955) revealed higher albumingamma globulin and albumin-total protein ratios in subdural hematoma effusions than in corresponding serum samples. Rabe et al (1962), confirmed Gitlin's findings and also demonstrated in an infant that I-131-labeled albumin, injected intravenously, had access to the fluid within the subdural cavity. Both Gitlin and Rabe believed that the fluid accumulation within the hematoma was due to effusion through damaged or pathologically permeable capillary walls.

Further clinical support to this effusion-rebleeding concept has been presented by Labadie and Glover (1974) who have shown persistently high levels of fibrinfibrinogen degradation products occurring in reforming human subdural effusions. Seemingly, plasma fibrinogen repeatedly enters the subdural cavity, clots, and then is rapidly lysed by a potent fibrinolytic activity available in situ. These presumptive alterations of hemostaticfibrinolytic mechanisms, appearing as a local hyperfibrinolytic state, may explain how repetitive rebleeding occurs.

Until recently, lack of an animal model of the subdural hematoma greatly hampered research. Goodell and Mealey (1963) interpreted their failure to produce a satisfactory animal model as a negative reflection on the osmotic-(oncotic) gradient theory. They attempted to "prime the osmotic pump" by repeated injections of clot into the same animals, simulating recurrent bleeding, yet the hematomas did not enlarge. Neither were they successful when inducing intracranial hypotension with cisternopleural shunts.

In 1972, Watanabe et al. lay claim to the first successful chronic subdural hematoma model. They pur- port that cerebrospinal fluid (CSF), if incorporated into a clot, alters blood coagulation to favor the formation of chronic subdural hematomas.

In their in vitro experiments, when fresh blood is mixed with CSF and allowed to clot and retract, and the clot is then immersed in distilled water, hemolysis of erythrocytes occurs rapidly and the contents diffuse out through the enveloping "membrane." They conclude that "this membrane is not semipermeable, and that no osmotic effect is being exerted in and out of this membrane." However, their "clot membrane" bears no resemblance to either the subdural neomembrane formed in vivo nor the arachnoid. Furthermore, the claimed alteration of the fibrin ultrastructure by CSF, as compared to physiologic saline, has been shown to be due to the absence of activation of factor XIII (fibrin stabilizing factor) because of the lack of ionized calcium in the saline control, and not due to any particular property of CSF (other than that it supplies a satisfactory concentration of ionized calcium.)

Despite these shortcomings, the in vivo experiments of Watanabe et al, cannot be discounted. They found that when a blood clot formed in the presence of CSF is inoculated into the subdural or subcutaneous space of dogs or monkeys, a progressive enlargement of the lesions ensued, having identical histological neomembrane characteristics, as compared with those found in human subdural hematomas. The growth is attributed to the peculiar mixture of blood and CSF. Watanabe et al also utilized inoculation of fibrin-cerebrospinal fluid clot mixtures, which later on were found to have fresh erythrocytes within. Presumably, this offers further evidence of chronic rebleeding.

Apfelbaum et al (1974), attempting to reproduce the results of Watanabe et al, verified that they could produce the main histological features of the "evolution of the subdural hematoma" in a dog and cat model, but concluded that they could not demonstrate any significant en- 
largement of the lesions. However, they did report that several of the subcutaneous lesions swelled $1 \frac{1}{2}$ to 2 times their original size, but concluded that the growth was "unrelated to the composition of the implant." Apfelbaum et al extend their own theory that "the tendency toward an increased bleeding time combined with less effective absorption, superimposed upon low intracranial pressure states, may explain the clinical features of chronic subdural hematoma formation in man and the failure to achieve these in small experimental animals."

The long term follow-up of patients with chronic subdural hematomas, arteriographically verified, who have been treated by medical means only (Bender, 1974) has shown that their natural evolution is toward a slow but complete reabsorption. This clinical data adds support to the concept of a balance between production and reabsorptive capacity, mostly explained by physical laws of the relationship between the membranes total surface and the volume of liquid contained in its semispherical shape. Volume would then increase at a faster rate than the sac surface as the lesion enlarges (Apfelbaum et al, 1974). Furthermore, most of the surgically treated cases (approx. 80\%) show a definite "cure" when the effusion is aspirated once. Those cases in which re-accumulations do occur, show a progressive decrement in volume as the re-aspirations are continued (Labadie and Glover, 1974).

\section{SUMMARY \\ (Continued from page 222)}

It has been virtually disproven that osmosis, referring to the electrolyte gradient as measured by freezing point depression, has any significance as a growth inducing factor.

The protein oncotic gradient theory, having been the most widely accepted explanation as to the progressive enlargement of the subdural hematoma sac, has little experimental data supporting it.

A larger body of clinical evidence exists supporting the concept that plasma and/or erythrocytes continuously penetrate into the subdural cavity, where enhanced fibrinolytic activity is present.
However, this chronic rebleeding cannot fully explain the observed growth, because the composition of the hematoma fluid is somewhat different from serum or plasma, and the protein content is also progressively diluted by fluid arising from an unknown source.

There is some clinical and experimental evidence to suggest that a production reabsorption balance may be a significant growth variable.

No work has been done to define the role, if any, of local inflammatory mechanisms in the chronic subdural hematoma.

Sound clinical evidence has shown that after the initial formation of the subdural clot, growth follows, then a slow, complete reabsorption usually occurs. Aside from the plausible production - reabsorption balance concept, it is not known why the evolution proceeds in this manner.

\section{RÉSUMÉ}

(Suite de la page 222)

- Il a été de fait réfuté qu'un mécanisme osmotique, i.e. le gradient electrolytique, mesuré par l'abaissement du point de congélation, aie quelque signification comme facteur entrainant la croissance de l'hématome.

- La théorie du gradient oncotique protéinique qui fut l'explication la mieux acceptée de l'augmentation progressive du sac de l'hématome sousdural, est en fait supportée par peu de données expérimentales.

- Certains faits cliniques supportent le concept que le plasma etlou les globules rouges, pénètre continuellement dans la cavité sousdurale, en plus d'une activité fibrinolytique augmentée. Cependant, ce saignement chronique ne peut pas expliquer entièrement la croissance observée, parce que la composition du liquide de l'hématome est quelque peu différente du sérum ou plasma, et que le contenu protéique est également dilué progressivement par un liquide prouvenant d'une source inconnue.

- Il y a quelques évidences cliniques et expérimentales qui suggèrent qu'une balance production-réabsorption peut être une variable significative du mécanisme de croissance.

- Il n'y a pas eu de travaux faits pour définir le rôle, s'il existe, du mécanisme inflammatoire local dans l'hématome sousdural chronique.

- Après la formation initiale d'un caillot sousdural, la croissance est la deuxième étape, suivie d'une lente et complète réabsorption. Sauf par le concept plausible de la balance production-réabsorption, on ne sait pourquoi l'évolution se poursuit de cette façon.

We wish to express our thanks to Dr. E. D. Warner for reviewing this manuscript and to Catherine McVeigh for help in preparation.

\section{REFERENCES}

APFELBAUM, R. I., GUTHKELCH, A. N., SHULMAN, K. (1974). Experimental production of subdural hematomas. Journal of Neurosurgery, 40, 336-346.

ARIEFF, A. I., WETZEL, N. (1964). Subdural hematoma following epileptic convulsion. Neurology (Minneap), 14, 731-732.

ARONSON, S. M. (1960). The pathogenesis of subdural hematoma, Paper read at the 2nd International Meeting on Forensic Pathology and Medicine, New York, Sept. 20, 1960. Cited by Peery (1971).

BAYLE, A. L. J. (1826). Traite de maladies du cerveau et de ses membranes. Paris. p. 250. Cited by Putnam (1925).

BECHAR, M., LAKKE, J. P., VAN DERHEM, G. K., BEKS, J. W., PENNING, L. (1972). Subdural hematoma during longterm dialysis. Archives of Neurology, 26, 513-516.

BELMUSTO, L., REGLESON, W., OWENS, G. et al. (1964). Intracranial extracerebral hemorrhages in acute lymphatic leukemia: a problem resulting from the chemotherapeutic modifications of acute leukemia. Cancer, 17, 1079-1088.

BENDER, MORRIS, personal communication of 106 cases of chronic subdural hematomas medically treated (to be published).

BOOP, W. C., Jr., CHOU, S. M., FRENCH, L. A. (1961). Ruptured intracranial aneurysm complicated by subdural hematoma. Journal of Neurosurgery, 18, 834-836.

CAPISTRANT, T., GOLDBERG, R, SHIBASKI, H., CASTLE, D. (1971). Posterior fossa subdural hematoma associated with anticoagulant therapy. Journal of Neurosurgery and Psychiatry, 34, 82-85.

CLARK, E., WALTON, J. M. (1953). Subdural hematoma complicating intracranial aneurysm and angioma. Brain, 76, 378-404.

CRUVEILHIER, J. (1856). Traite d'anatomie pathologique, Paris, 3, 515. Cited by Putnam (1925).

DOOLEY, D. M., PERIMUTTER. (1964). Spontaneous intracranial hematomas in patients receiving anticoagulant therapy. Journal of the American Medical Association, 187, 396-398.

GARDNER, W. J. (1932). Traumatic subdural hematoma: with particular reference to the latent interval. Archives of Neurology and Psychiatry, 27, 847-858. 
GARDUS, G. (1964). Two cases of subdural hematoma complicating anticoagulant therapy. Central Africa Journal of Medicine, 10, 188-291.

GITLIN, D. (1955). Pathogenesis of subdural collections of fluid, Pediatrics, 16, 345-352.

GLASER. (1866). Vereitertes Hamaton der Dura Mater, Deutsche medizinische wochenschrift, 12, 815. Cited by Putnam (1925).

GOODELL, C. L., MEALEY, J., Jr. (1963). Pathogenesis of chronic subdural hematoma. Experimental studies. Archives of Neurology, 8, 429-437.

HESCHL, R. (1855). Kornpendium der allgemeinen and Speciellen pathologschen Anatomie, Vienna, p. 291. Cited by Putnam (1925).

KASEMYER, E. (1912). Post-traumatische Pachymeningitis, Tod 5 Vahre nach-dem Unfall, Deutsche medizinische wochenschrift, 38, 2020. Cited by Putnam (1925).

KERR, C. B. (1964). Intracranial hemorrhage in hemophilia. Journal of Neurology, Neurosurgery and Psychiatry, 27, 166-173.

KLUCK, M. (1890). Ein Fall von vereitertem hematoma durae matris, Inaugural Dissertation, Greifswald. Cited by Putnam (1925).

LABADIE, E., GLOVER, R. D. Local alterations in hemostatic - fibrinolytic mechanisms in reforming subdural hematomas. Submitted 1974.
LEONARD, C. D., WEIL, E., SCRIBNER, B. H. (1969). Subdural hematomas in patients undergoing hemodialysis. Lancet, 2 , 239-240.

LERNER, P. J., GOLDEN, P. F., JANE, J. A. (1972). Salmonella infected subdural hematoma. Pediatrics, 49, 127-128.

MUNRO, D., MERRITT, H. H. (1936). Surgical pathology of subdural hematoma based on a study of 105 cases. Archives of Neurology and Psychiatry, 35, 64-79.

PEERY, M. T., and MILLER, G. M. (1971). Pathology: A dynamic introduction to medicine and surgery. Little, Brown and Company, Boston, pp. 212-213.

PUTNAM, P. J., CUSHING, H. (1925) Chronic subdural hematoma; its pathology, its relation to pachymeningitis hemorrhagica and its surgical treatment. Archives of Surgery, 11, 331-393.

RABE, E. F., FLYNN, R. E., DODGE, P. R. (1962). A study of subdural effusions in an infant, with particular reference to their mechanisms of persistance. Neurology, 12, 79-92.

SREERAMA, V., IVAN, L. P., DENNERY, J. M., RICHARD, T. M. (1973). Neurological complications of anticoagulant therapy. Canadian Medical Association Journal, 108, 305-307.

TALALLA, A., HOLBROOK, H., BARBOUT, B. H. (1970). Subdural hematoma associated with long term hemodialysis for chronic renal disease. Journal of the American Medical Association, 212, 1847-1849.

VIRCHOW, R. (1863). Die Krankhaften Gaschwelste, Berlin 1, 140. Cited by Putnam (1925).

WATANABE, S., SHIMADA, H., ISHII, S. (1972). Production of chronic subdural hematoma in experimental animals. Journal of Neurosurgery, 37, 552-561.

WEIR, B. (1971). The osmolality of subdural fluid. Journal of Neurosurgery, 34, 518-533.

WELLS, F. L. (1892). An interesting case of subdural intracranial hemorrhage (without fracture); Leptomeningitis: Trephining: Recover. Medical Recordings, 41, 541-542.

WOLCOT, G. T., GRONNET, M. L. LAHEY, M. E. (1970). Spinal subdural hematoma in a leukemic child. Journal of Pediatrics, 77, 1060-1062.

ZACHER. (1833). Doppelseitige Stauvngspapille mit Perineuritis bei Hamtom der Dura Mater, Neurologie Centralblatt 2: 125-132. Cited by Putnam (1925).

ZAROWNY, D. D., ROSE, I. (1970). Acute subdural hematoma during maintenance hemodialysis. Canadian Medical Association Journal, 103, 634.

ZOLLINGER, R., GROSS, R. E. (1934) Traumatic subdural hematoma; an explanation of the late onset of symptoms. Journal of the American Medical Association, 103 245-249. 